\title{
Kinky Coat, a New Autosomal Recessive Mutation in the Musk Shrew, Suncus murinus
}

\author{
Akira ISHIKAWA, Kanjun HIRUNAGI*, Sen-ichi ODA**, \\ Takao NAMIKAWA, and Takeshi TOMITA
Laboratory of Animal Genetics and*Laboratory of Veterinary Anatomy, Faculty of Agriculture, and ${ }^{* *}$ Research Institute of Environmental Medicine, Nagoya \\ University, Furo-cho, Chikusa-ku, Nagoya-shi, Aichi 464-01, Japan
}

(Received 19 November 1991/Accepted 25 December 1991)

\begin{abstract}
A kinky-coat mutant was discovered at the fifth generation of the BAN strain originating from wild musk shrews (Suncus murinus) in Bangladesh. Mating experiments indicated that the kinky-coat character is controlled by a single autosomal recessive gene designated $k c$ (kinky coat), which is not allelic to the gene ch (curly hair) previously reported in the $\mathrm{Tr}$ strain derived from wild musk shrews on Taramajima Island, Japan. Because the $k c / k c$ homozygotes were fully fertile and viable, the $k c$ gene should be useful as a genetic marker in linkage studies. In external appearance, homozygotes were characterized by curly vibrissae, somewhat unkempt coat hair, and wavy long hair on the tail. Both the length and width of coat hair did not differ significantly between homozygous and normal shrews. Light microscopic observations showed that shafts of the $k c$ coat hair are wavy and often have small swellings with disorganization of the medullary structure. Scannig electron microscopic examinations further revealed that the shafts of the vibrissae, coat hair, and tail hair have abnormalities such as longitudinal fissures, twists, and hollows. It is clear that these modifications caused waviness or curling of the shafts of the three kinds of hairs observed. - KEY WORDS : genetic marker, hair abnormality, recessive mutation, suncus murinus
\end{abstract}

Rexoid mutants have been recorded in various mammalian species, such as the house mouse [11], rat [5], rabbit [2], Guinea pig [19], and cat [17]. The mutant phenotypes are inherited as recessives or dominants to normal coats. They are characterized by bent or curled vibrissae and by curved or wavy coat hairs which are shorter and/or thinner than normal.

A curly hair mutation controlled by a single autosomal recessive gene (symbol $c h$ ) has been found in the musk shrew, Suncus murinus $[13,14]$. The mutant arose in the $\operatorname{Tr}$ strain derived from wild shrews on Taramajima Island, Japan. The ch/ch homozygotes are fully viable and fertile. They have curly vibrissae, wavy coat, and curled long hair on the tail. These traits remain throughout life.

In March 1987, we found a kinky-coat female musk shrew in the BAN strain originat- ing from wild shrews in Bangladesh. Genetic analysis provided evidence for the inheritance of the kinky-coat character as a single autosomal recessive gene. Phenotypically, the kinkycoat mutant resembles the curly-hair mutant described above in terms of the bent vibrissae and curled tail. However, coat hair is less curved in the kinky-coat mutant than in the curly-hair mutant.

In the present study, we describe the genetic basis and morphological characteristics of the kinky-coat mutation in the BAN strain of the shrew. We also test for allelism between the kinky-coat and curly-hair loci.

\section{Materials and Methods}

Origin : The history of the BAN strain of musk shrews was previously reported by Ishi- 
kawa et al. [8]. The BAN strain has been maintained as a closed breeding colony in the Laboratory of Animal Genetics, Nagoya University. Deliberate selection and close inbreeding have been avoided. General husbandry of the shrews is described by Ishikawa et al. [8].

The kinky-coat mutant was first discovered in one young female at the time of weaning at the fifth generation of the BAN strain. The phenotype of her single littermate could not be observed because of its death a few days after birth. The incidence of the kinkycoat mutant could not be traced in other litters from the same parents, both of which were phenotypically normal, because the sire had been discarded before the birth of the original mutant. It is unknown from an examination of the pedigree record of the BAN strain whether the mutant gene arose spontaneously in the BAN strain or was present in the original breeding stock as carriers.

Mating Experiments : Mating experiments were performed within the BAN strain to examine the mode of inheritance for the kinky coat. First filial progeny were produced from reciprocal crosses between mutant shrews and normal controls, and their subsequent $\mathrm{F}_{2}$ and backcross generations were produced. The normal controls used were defined as $+/+$ shrews with a confidence (mean $\pm S E$ ) of $84.5 \pm 4.0 \%$.

To precisely confirm the mode of inheritance for the kinky coat and to test for allelism between the kinky-coat and curlyhair loci, the kinky-coat shrews in the BAN strain were outcrossed to non-related, curlyhair shrews in the $\mathrm{Tr}$ strain. The $\mathrm{Tr}$ strain was transferred to our laboratory from the Research Institute of Environmental Medicine, Nagoya University. The BAN strain shrews are about 3 times heavier than the $\operatorname{Tr}$ strain shrews [10]. Because Ishikawa et al [9] suggest that mating success in this species is achieved only when females are nearly as heavy as males or lighter, the large kinky-coat males in the BAN strain were crossed to the small curly-hair females in the $\mathrm{Tr}$ strain. The $F_{1}$ hybrids produced from this cross were backcrossed to the kinky-coat shrews.

The matings described above were conducted for 2 days in single pairs. The mutant character of the obtained progeny was observed at 5 days after birth, because 1) we have found from experience that the handling of pups during the first 5 days after birth frequently causes the mother to eat her young; and 2) the mutant shrews could be clearly distinguished from their normal littermates by their curly vibrissae (Fig. 1).

Fertility and Viability : Percent parturition, litter size, percent pup survival, and body weight were recorded on the homozygotes, heterozygotes, and homozygous normal controls employed in the above-mentioned mating experiments. Percent parturition was defined as the proportion of total number of parturitions to total number of mating trials. Litter size was determined at 5 days of age. Pup survival was defined as the percentage of total number of pups weaned at 20 days to total number of pups observed at 5 days. Young were weighed at the time of weaning.

Hair Morphology : Hair samples were obtained from 4 young and 8 adult homozygous kinky-coat shrews and, for comparison, from 3 young and 7 adult heterozygous normal-coat animals. The young were 42 or 50 days of age and the adults were between 5 and 10 months old for both phenotypes. Coat hair was cut away from the middorsal region with safety razors; vibrissae and long hair on the tail were obtained with scissors. These hair samples were air-dried and stored at room temperature.

Hair samples were analyzed in three ways. First, the length and maximum width of coat hair, without any treatment, were measured through the use of an ocular micrometer. Second, the shaft structure of coat hair was examined under light microscopy. The coathair samples were dehydrated and cleared in alcohol, alcohol-xylene, and xylene, followed by embedding in Canada balsam. Last, the surface texture of the shafts of coat hair, vibrissae, and tail hair was investigated by means of scanning electron microscopy. The samples of these three kinds of hair were mounted on specimen stubs with double-sided adhesive tape and coated with gold in an ion sputter unit (JFC-100, Jeol, Co., Ltd., Tokyo). The samples were observed under a scanning electron microscope (JSM F-7, Jeol, Co., Ltd., Tokyo) operating at $7 \mathrm{kV}$.

\section{Results}

Genetics: The results of mating experi- 
Table 1. Segregation of the kinky coat $(k c)$ in musk shrews at 5 days after birth

\begin{tabular}{|c|c|c|c|c|c|c|}
\hline \multirow{2}{*}{$\begin{array}{l}\text { Mating } \\
+\times \quad \hat{\delta}\end{array}$} & \multirow{2}{*}{$\begin{array}{l}\text { No. of } \\
\text { mating }\end{array}$} & \multirow{2}{*}{$\begin{array}{c}\text { No. of } \\
\text { offspring }\end{array}$} & \multicolumn{2}{|c|}{ Phenotype of offspring } & \multirow{2}{*}{$\begin{array}{l}\text { Expected ratio }^{\mathrm{a}} \\
\text { Normal : Kinky }\end{array}$} & \multirow{2}{*}{$\chi^{2}$} \\
\hline & & & Normal & Kinky & & \\
\hline$k c / k c^{\mathrm{b}} \times+/+$ & 9 & 26 & 26 & 0 & $1: 0$ & \\
\hline$+/+\times k c / k c$ & 5 & 13 & 13 & 0 & $1: 0$ & \\
\hline Total & 14 & 39 & 39 & 0 & $1: 0$ & \\
\hline$k c / k c \times+/ k c$ & 18 & 67 & 26 & 41 & $1: 1$ & $3.36^{\mathrm{NS}}$ \\
\hline$+/ k c \times k c / k c$ & 2 & 6 & 5 & 1 & $1: 1$ & \\
\hline Total & 20 & 73 & 31 & 42 & $1: 1$ & $1.66^{\mathrm{NS}}$ \\
\hline$+/ k c \times+/+$ & 10 & 37 & 37 & 0 & $1: 0$ & \\
\hline$+/+\times+/ k c$ & 2 & 9 & 9 & 0 & $1: 0$ & \\
\hline Total & 12 & 46 & 46 & 0 & $1: 0$ & \\
\hline$+/ k c \times+/ k c$ & 14 & 54 & 37 & 17 & $3: 1$ & $1.21^{\mathrm{Ns}}$ \\
\hline$k c / k c \times k c / k c$ & 8 & 29 & 0 & 29 & $0: 1$ & \\
\hline
\end{tabular}

Mutant pups were identified by their curly vibrissae (see Fig. 1). a Based on simple autosomal recessive inheritance ${ }^{b}$ Presumed genotype Ns Not significantly different from the expected ratio at $P<0.05$

ments within the BAN strain, summarized in Table 1, agreed closely with expectations based on simple autosomal recessive inheritance. The nearly Mendelian ratios indicated that the mutant character is of full penetrance.

A test for allelism was performed between kinky-coat males in the BAN strain and curlyhair females in the $\operatorname{Tr}$ strain. The 6 male and 6 female $F_{1}$ progeny obtained from the 4 matings were slightly abnormal in external appearance, but the phenotypes usually made it difficult to positively distinguish the $F_{1}$ shrews from normal controls. The tip of their vibrissae were slightly bent forward toward the mouth. The long hair on the tail was slightly curved. These traits persisted in adults, but the coat hair looked normal throughout life. We inferred that the external characteristics appearing in the $F_{1}$ shrews were caused by the influence of the ch gene conditioning the curly-hair character, because 1) such traits were reported to appear in the $+/$ ch phenotype [14] ; and 2) heterozygotes for the kinky-coat gene could not be distinguished from homozygous normal controls by light microscopic and scanning electron microscopic examinations of the hair, which will be discussed in Hair Morphology. We thus classified the $F_{1}$ shrews as phenotypically normal.

To confirm the independent expression of the two mutant genes, the $F_{1}$ females were backcrossed to the kinky-coat males. The 5 matings produced 13 normal and 10 mutant shrews, the segregation ratio of which was in good agreement with the expected $1: 1$ ratio hypothesized for the independence of the two genes $\left(\chi^{2}\right.$-test, $\left.0.50<P<0.70\right)$.

From the above results, we conclude that the kinky-coat character is controlled by a single autosomal recessive gene which is not allelic to the ch gene. Accordingly, we propose the symbol $k c$ (kinky coat) for the present mutant gene found in the BAN strain of the musk shrew.

Fertility and Viability : Table 2 shows reproductive abilities for the $k c / k c,+/ k c$, $+/+$ shrews. There were no significant differences in both percent parturition $\left(\chi^{2}\right.$-test or Fisher's exact probability test) and litter size ( $t$-test) among the three genotypes at $P<0.05$. Five heterozygous pups died from unknown factors at about 5 days of age, leading to significantly lower pup survival (95.1 $\%)$ than for the $k c / k c$ shrews (100.0\%).

Table 3 presents details of mean body weight at weaning for the three genotypes. For males, mean body weight of the $+/ k c$ shrews was significantly higher than those of the other genotypes for unknown reasons. For females, there were no significant differences among the three genotypes in body weight. The body weights of the three genotypes for both sexes were not significantly different (at $P<$ $0.05, t$-test or Cochran-Cox test) from those 
Table 2. Reproductive performance in kinky-coat and normal-coat musk shrews

\begin{tabular}{|c|c|c|c|c|c|}
\hline \multirow[b]{2}{*}{ Genotype $^{a}$} & \multirow{2}{*}{$\begin{array}{c}\% \\
\text { Parturition }\end{array}$} & \multicolumn{3}{|c|}{ Litter size at 5 days after birth } & \multirow{2}{*}{$\begin{array}{c}\% \text { Pup } \\
\text { survival } \\
\text { at weaning }\end{array}$} \\
\hline & & $(n)^{c}$ & Mean $\pm S D$ & Range & \\
\hline$k c / k c$ & $\begin{array}{c}54.7 \\
(35 / 64)\end{array}$ & (35) & $3.5 \pm 1.0$ & $2-6$ & $\begin{array}{l}100.0^{\mathrm{e}} \\
(122 / 122)\end{array}$ \\
\hline$+/ k c$ & $\begin{array}{c}51.9 \\
(28 / 54)\end{array}$ & (28) & $3.7 \pm 1.4$ & $1-7$ & $\begin{array}{l}95.1^{f} \\
(98 / 103)\end{array}$ \\
\hline$+/+$ & $\begin{array}{c}70.0 \\
(7 / 10)\end{array}$ & (7) & $3.1 \pm 1.6$ & $1-5$ & $\begin{array}{l}100.0^{\text {ef }} \\
(22 / 22)\end{array}$ \\
\hline
\end{tabular}

a Genotypes of mothers employed in the mating experiments shown in Table 1

b Proportion of total number of parturitions to total number of mating trials is indicated in parentheses. c Number of litters observed d Proportion of total number of pups weaned at 20 days after birth to total number of pups observed at 5 days is given in parentheses. e, $f$ Values with the same letters are not significantly different at $P<0.05$ (Fisher's exact probability test)

Table 3. Body weight (g) at weaning (20 days after birth) among kinky-coat and normal-coat musk shrews

\begin{tabular}{lccc}
\hline Genotype $^{\mathrm{a}}$ & $\mathrm{n}^{\mathrm{b}}$ & Mean $\pm S D$ & Range \\
\hline Male & & & \\
$k c / k c$ & 38 & $56.2 \pm 10.0^{\mathrm{d}}$ & $30.8-76.1$ \\
$+/ k c$ & 24 & $63.8 \pm 11.3^{\mathrm{e}}$ & $36.6-80.1$ \\
$+/ \mathrm{c}$ & 37 & $57.8 \pm 9.2^{\mathrm{d}}$ & $42.0-74.7$ \\
Female & & & \\
$k c / k c$ & 49 & $47.9 \pm 7.7$ & $23.8-64.3$ \\
$+/ k c$ & 37 & $48.6 \pm 6.5$ & $33.6-62.9$ \\
$+/ \mathrm{c}$ & 38 & & $36.3-61.5$ \\
\hline
\end{tabular}

a Genotypes of progeny produced from the mating experiments shown in Table 1

b Number of shrews weighed $\quad c+/ k c$ or $+/+d$ e Means with the same letters are not significantly different at $P<0.05$ ( $t$-test) for males; there are no significant differences between any genotypes for females

of the $+/+$ control shrews $(62.9 \mathrm{~g}$ in males and $46.6 \mathrm{~g}$ in females) previously reported by Ishikawa and Namikawa [7].

From the above results, it is clear that the $k c$ gene is not exerting any appreciable effect on fertility and viability.

External Appearance : Figure 1 shows gross appearances of a kinky-coat homozygote and its normal littermate at 5 days of age. The homozygote had strongly curled vibrissae. The colorless guard hair sparsely covering the body at this age was irregularly curved or crooked and tended to be close to the body surface, compared with the straight guard hair of the normal littermate. At weaning (20 days of age), the coat hair was somewhat unkempt or untidy. The long hair on the tail was extremely wavy. These mutant traits persisted in adult shrews (Fig. 2).

Hair Morphology : Under light microscopy, the coat hair from mid-dorsum of adult heterozygous normal shrews was grouped into three distinct types ( $\mathrm{A}, \mathrm{B}$, and $\mathrm{C})$, according to the criteria employed in the mouse [3], such as the number of rows of medullary cells and the presence or absence of constrictions in the shaft. Very few intermediate types are normally found.

Type $A$ is the overhair which has no constrictions. The thin parts of the shaft have one row of medullary cells. In the broader parts of the shaft, there may be two rows which are often very ill defined and usually become continuous because of the denselypigmented medullary cells. The pigmentation is present in the medulla, but can not be seen 
Table 4. Measurements (mean $\pm S D$ ) of three coat-hair types $(A, B$, and $C$ ) from adult kinky-coat $(k c / k c)$ and normal-coat $(+/ k c)$ musk shrews

\begin{tabular}{|c|c|c|c|c|c|c|c|}
\hline \multirow{2}{*}{$\begin{array}{l}\text { Hair } \\
\text { type }\end{array}$} & \multirow{2}{*}{$\begin{array}{l}\text { Segment } \\
\text { of hair }{ }^{b}\end{array}$} & \multicolumn{4}{|c|}{ Length (mm) } & \multicolumn{2}{|c|}{ Maximum width $(\mu \mathrm{m})$} \\
\hline & & \multicolumn{2}{|r|}{$k c / k c$} & \multicolumn{2}{|r|}{$+/ k c$} & $k c / k c$ & $+/ k c$ \\
\hline $\mathrm{A}$ & $1 \mathrm{st}$ & $(8)^{c}$ & $5.9 \pm 0.7$ & (5) & $7.6 \pm 1.8$ & (8) $49 \pm 2$ & (5) $50 \pm 3$ \\
\hline \multirow[t]{2}{*}{$\mathrm{B}$} & 1 st & $(8)$ & $3.1 \pm 0.4$ & (6) & $2.9 \pm 0.6$ & (8) $41 \pm 3$ & (6) $38 \pm 3$ \\
\hline & 2nd & (8) & $1.4 \pm 0.3$ & (6) & $1.3 \pm 0.5$ & (8) $19 \pm 5$ & (6) $18 \pm 4$ \\
\hline \multirow[t]{4}{*}{$\mathrm{C}$} & 1 st & (6) & $0.9 \pm 0.1$ & (5) & $0.9 \pm 0.1$ & (6) $11 \pm 2$ & (5) $12 \pm 3$ \\
\hline & 2nd & (6) & $1.1 \pm 0.1$ & (5) & $1.2 \pm 0.1$ & (6) $20 \pm 0$ & (5) $20 \pm 0$ \\
\hline & $3 \mathrm{rd}$ & (6) & $0.9 \pm 0.1$ & (5) & $1.0 \pm 0.0$ & (6) $15 \pm 0$ & (5) $17 \pm 3$ \\
\hline & 4 th & (6) & $0.8 \pm 0.2$ & (5) & $0.6 \pm 0.3$ & (6) $9 \pm 4$ & (5) $12 \pm 2$ \\
\hline
\end{tabular}

a Classified according to the criteria described by Dry [3] of the three hair types are described in the text

Characteristics divided into some segments by constrictions in the hair shrews examined

b Each hair type was

c Number of in the cortex of all hair types from the BAN shrews covered with light-gray coat. By contrast, Japanese shrews with dark-gray coat generally have a medulla and cortex both of which are pigmented (our unpublished data).

Type B hair with a single constriction and Type $C$ hair with two or three constrictions are both underhairs shorter in total length and thinner than Type A hair (Table 4). The hairs of both Types B and $\mathrm{C}$ are divided into some segments by the constrictions : the first segment is the region from the tip to the first constriction, the second segment is the region between the first and second constrictions, and so on. The first segment of Type B hair has one or two rows of medullary cells wholly pigmented, but small pigment clumps are of ten found proximally. The second segment of Type B hair and all segments of Type C hair both have only one row of medullary cells completely filled with pigment granules, and they look like a ladder. Type $\mathrm{C}$ hair especially resembles the zigzag hair of the mouse [3] in light microscopic appearance.

Adult kinky-coat shrews had all of the three types of coat hair present in heterozygous shrews. For each hair type, both the length and maximum width did not differ significantly between the $k c / k c$ and $+/ k c$ shrews at $P<$ 0.05 ( $t$-test or Cochran-Cox test), as shown in Table 4.

Figure 3 shows light microscopic appearances of coat hair from adult homozygotes and heterozygotes. Two distinct kinds of abnormalities were detected for the shafts of the mutant coat. First, the shafts of all types of the coat hair from homozygotes were strongly waved, compared with the corresponding straight hair shafts from heterozygotes (Fig. $3 \mathrm{~A}$ to $\mathrm{F}$ ). These waves were also observed for younghomozygous coat. Numerous variations were noted in both range and degree of the waviness within and among hair types from the sameshrews. The regions showing waviness never coexisted with obvious abnormal structures suchas irregular arrangement of the medullary cells and abnormal shaft diameter. Second, homozygote shafts of ten had small swellings with thedisorganization of medullary structure (Fig. 3G to J). The small, different-sized swellings within and among hair types were frequently found in the first segment of Type B hair andthe second or third segment of Type $\mathrm{C}$ hair. Bycontrast, none of the 7 adult nor 3 young heterozygotes had such swellings in their shaftsfor all of the hair types.

Figure 4 shows scanning electron photomicrographs of coat hair, vibrissae, and long hair on the tail from homozygotes and heterozygotes. Three kinds of hairs from adult and young homozygotes commonly showed swellings, longitudinal fissures, twists, and hollows of the shafts. The pattern of the cuticular scales appears to be normal despite the shaft irregularity. Some of the hollows observed were conceivably marks artificially made with tweezers when we obtained the hair samples, because small cracks sometimes were found in the hollows. However, it was rare to observe 
heterozygotes with such artificially-made hollows in any kind of hair. It thus seems that the shafts of the homozygous hair are injured easily.

In addition to the above- mentioned abnormalities, the coat hair from homozygotes of ten had flat or corrugated shaft configuration (Fig. $4 \mathrm{D}$ ). The corrugation also was seen for the vibrissae. A complication of some abnormalities was frequently found in shafts of all kinds of hairs. All the abnormalities observed were generally found in various parts of the shafts of the coat hair and tail hair, whereas they were frequently seen in the proximal regions of the vibrissae.

The coat hair, vibrissae, and tail hair of the $+/ c k$ and $+/+$ shrews were little affected in scanning electron microscopic appearance, but their coat hairs occasionally showed slight longitudinal fissures of the shafts.

It is clear that the shaft modifications discovered under the scanning electron microscope (Fig. 4) caused waviness or curling of the shafts of the coat hair, vibrissae, and tail hair seen in the gross or light microscopic appearance (Figs. 2 and 3 ).

\section{Discussion}

Kinky coat is the second mutation of this kind in the musk shrew. The first is the curly hair reported by Oda $[13,14]$. We could not compare the hair structure between the two mutants in detail, because the microscopic examination of the hair from $\mathrm{ch} / \mathrm{ch}$ shrews has not been performed.

The kinky-coat $(k c)$ gene was not observed to have pleiotropic effects. Bennett and Greshman [1], however, found that in many mice homozygous for the waved-1 (wa-1) gene, which causes curly vibrissae and waved coat, the eyelids are open at birth. In the rat, the zitter (zi) gene, which causes an ataxic disorder, is reported to produce a hair anomaly [15]. The $k c$ gene in the musk shrew should be useful as a morphological genetic marker in linkage studies, because the gene is shown to have good penetrance (Table 1) and to be fully fertile and viable (Tables 2 and 3 ). Only two visible markers, the curly-hair (ch) gene [13, 14] and the cream (cr) gene for coat color [6], have so far been reported in the shrew.

Laboratory rodents are well known to have a great array of rexoid mutants, and detailed studies have been made on their mutant characters $[4,5,11,19]$. The kinky-coat shrews in the present report resemble the fuzzy $(f z)$ mice both in its recessive inheritance and in the way the coat hair remains waved or curled throughout life. The shrews differ, however, in that the fuzzy coat is thin and the hair types are less readily distinguishable from each other than normal $[12,18]$. In addition, the shrews differ from the soft-coat (soc) mice which have thin coat-hair with occasional irregularities in diameter [18] .

No kinky-coat shrews exhibited the alopecia which appears in rexoid mutants such as the wavy coat $\left(R e^{W C}\right)$ in the mouse [18] and the kinky $(k)$ and rex $(R e)$ in the rat [16]. Moreover, the $k c / k c$ shrews differ from the wavy-coat mice which show variation in shaft diameter with overpigmentation of the medulla and disruption of the normal pattern of cuticular scales [18]. Nevertheless, the shaft modifications such as swellings, twists, and longitudinal indentations in the $k c / k c$ shrews (Figs. 3 and 4) are surprisingly similar to those of the wavy-coat mice [18].

It is clear that the hair structure of the kinky-coat mutant does not closely resemble any of the previously-described rexoid mutants of laboratory rodents. Because the $k c / k c$ shrew is characterized by much simpler phenotypes than the rexoid laboratory rodents, it may be valuable for studying the genetic regulation of hairgrowth.

\section{References}

[1] Bennett, J H. and Gresham, G. A. (1956). A gene for eyelids open at birth in the house mouse. Nature, 178, 272-273.

[2] Castle, W. E. and Nachtsheim, H. (1933). Linkage interrelations of three genes for rex coat in the rabbit. Proc. Nat. Acad Sci USA 19, 1006-1011.

[3] Dry, F. W (1926). The coat of the mouse (Mus musculus). J. Genet., 16, 287-340.

[4] Greaves, J. H.(1981). Wavy : a new recessive rexoid mutant in the Norway rat. J. Hered, 72, 291-292.

[5] Hedrich, H. J. (ed.) (1990). Genetic Monitoring of Inbred Strains of Rats. Gustav Fischer Verlag, Stuttgart.

[6] Iseki, R., Namikawa, T., and Kondo, K. (1984). Cream, a new coat-color mutant in the musk shrew. J. Hered, 75, 144-145.

[7] Ishikawa, A. and Namikawa, T. (1987). Postnatal growth and development in laboratory strains of large and small musk shrews (Suncus murinus). $J$. 
Mammal, 68, 766-774.

[8] Ishikawa, A., Tsubota, Y., and Namikawa, T (1987). Morphological and reproductive characteristcs of musk shrews (Suncus murinus) collected in Bangladesh, and development of the laboratory line (BAN line) derived from them. Exp. Anim, 36, 253260.

[9] Ishikawa, A., Yamagata, T., and Namikawa, T. (1991). An attempt at reciprocal crosses between labororatory strains of large and small musk shrews (Suncus murinus) - influence of body-weight difference between sexes on mating success. Exp. Anim, 40, 145-152.

[10] Ishikawa, A., Akadama, I., Namikawa, T., and Oda, S (1989). Development of a laboratory line (SRI line) derived from the wild house musk shrew, Suncus murinus indigenous to Sri Lanka. Exp. Anim, 38, 231-237.

[11] Lyon, M. F. and Searle, A. G. (1989). Genetic Variants and Strains of the Laboratory Mouse, 2 nd ed. Oxford Univ. Press, Oxford.

[12] Mann, S. J. (1964). The hair of the fuzzy mouse $J$. Hered, 55, 121-123.
[13] Oda, S. (1985). Curly hair, a new mutation in the house musk shrew, Suncus murinus Ann Report Res. Inst. Environ Med, Nagoya Uniw., Japan, 36, 226-227. (in Japanese).

[14] Oda, S. (1989). Genetic analysis of a curly hair character in the house musk shrew, Suncus murinus Ann. Report Res Inst. Environ Med, Nagoya Uniw., Japan, 40, 268-271. (in Japanese).

[15] Rehm, S., Mehraein, P., Anzil, A. P., and Deerberg, F. (1982). A new rat mutant with defective overhairs and spongy degeneration of the central nervous system : clinical and pathological studies. Lab. Anim Sci, 32, 70-73.

[16] Robinson, R. (1981). Rex mutant in the Norway rat. $J$ Hered, 72, 131-132.

[17] Robinson, R. (1982). Dutch rex-fifth rexoid coat mutant in the cat. Genetica, 57, 217-218.

[18] Trigg, M. J. (1972). Hair growth in mouse mutants affecting coat texture. J. Zool, Lond, 168, 165-198.

[19] Whiteway, C. E. and Robinson, R. (1989). Two recessive rex coat mutants in the Guinea pig. $J$. Hered, 80, 163-165.

\title{
スンクス (Suncus murinus)に発見された縮毛 ミュータントの遺伝解析と形質の特徵
}

石川明・蛭薙 観順*・織田 銑一**・並河鷹夫 ·富田武

\author{
名古屋大学農学部家畜育種学教室 \\ *名古屋大学農学部生体機構学教室 \\ $* *$ 名古屋大学環境医学研究所
}

バングラデシュを起源とするスンクス (Suncus murinus) BAN 系統の 5 世代目に打いて，縮毛を呈す るミュータントが発見された。交配実験の結果, この ミュータント形質は, 常染色体性単一の乓性遺伝子 $k c$ (kinky coat)によって支配されていることが明らかに された。沖縄県多良間島由来の Tr系統に怙いて，常染 色体性単一の劣性遺伝子 ch (curly hair) に上って支配 されている巻毛ミュータントが報告されている。対立性 の検定を行ったところ, $k c$ と $c h$ 遺伝子は異なった遺伝 子座にあることが判明した。 $k c / k c$ ホモ型個体はほぼ正 常な生存・繁殖能力を有していたので，この遺伝子は有
用な遺伝標識になるものと考えられた。外観上，ホモ型 個体は触毛打よび尾毛の顕著な縮れと体毛のわずかな縮 れによって特徵づけられた。体毛の長さと幅にはホモ型 と正常個体間で有意な羑異はみられなかった。体毛を光 学顕微鏡下で観察すると, ウェーブまたは㖪質構造の異 常を伴ら膨らみが観察された。また，触毛，体毛および 尾毛を走査型電子顕微鏡下で観察すると，これら 3 種の 毛には, 裂溝, ねじれ，宔みなどの変形がみられた。こ れらの変形が，外観および光学顕微鏡下で観察された 3 種の毛の縮れまたはウェーブを引き起こしているものと 考えられた。 


\section{Explanation of Figures}

Fig. 1. A normal-coat musk shrew ( $A$ and $C$ ) and the kinky-coat littermate ( $B$ and $D$ ) at 5 days of age. Before growing a kinky coat, the mutant pup is readily distinguishable from the normal sib by the curly vibrissae.

Fig. 2. (A) Straight vibrissae of a heterozygous normal-coat musk shrew about 11 months old (left) and curled vibrissae of a homozygous kinky-coat musk shrew about 7 months old (right). (B) Straight long hair on the tail of the $+/ k c$ shrew (top) and wavy long hair of the $k c / k c$ shrew (bottom).

Fig. 3. Light micrographs of coat hair from the $+/ k c$ and $k c / k c$ musk shrews. (A) Proximal region of $\mathrm{a}+/ k c$ Type $\mathrm{A}$ hair at about 10 months of age (X 32). (B) Proximal region of a $k c / k c$ Type A hair at about 6 months (X 32). (C) Proximal region of first segment of $a+1$ $k c$ Type B hair from the same shrew as in $(A)$ (X 32). (D) Proximal region of first segment of a $k c / k c$ Type B hair from the same shrew as in $(B)$; narrow base of the shaft shows a constriction (X 32). (E) Middle region of second segment of a $+/ k c$ Type $\mathrm{C}$ hair from the same shrew as in $(A)(\mathrm{X} 80)$. (F) Middle region of second segment of a $k c / k c$ Type $\mathrm{C}$ hair at about 5 months (X 80). (G) Shaft swelling with a breakdown of medullary structure on first segment of a $k c / k c$ Type $\mathrm{B}$ hair at about 6 months (X 80). (H) High magnification of (G) (X 320). (I) Shaft bulging with the disorganization of medullary structure on second segment of a $k c / k c$ Type $\mathrm{C}$ hair at about 7 months (X 80). (J) High magnification of (I) (X 320). See text for explanation of characteristics of the three coat hair types.

Fig. 4. Scanning electron micrographs of coat hair, vibrissae, and long hair on the tail from the $+/ k c$ and $k c / k c$ musk shrews. (A) Middle region of $a+/ k c$ Type A coat hair at about 6 months of age (X 500). (B) Middle region of a $k c / k c$ Type $\mathrm{A}$ coat hair at 50 days (X 500), showing a longitudinal fissure and swelling of the shaft. (C) Proximal region of first segment of a $+/ k c$ Type B coat hair at about 6 months (X 500). (D) Proximal region of first segment of a $k c / k c$ Type B coat hair at about 5 months (X 500), exhibiting a slight twisting and corrugation of the shaft. (E) Proximal region of a $+/ k c$ vibrissa from the same shrew as in (A) (X 300). (F) Proximal region of a $k c / k c$ vibrissa from the 6-monthold shrew used in (B) (X 300), showing a longitudinal indentation or hollows. (G) Proximal region of $\mathrm{a}+/ k c$ long hair on the tail from the same shrew as in $(A)(\mathrm{X} 300)$. (H) Proximal region of a $k c / k c$ long hair on the tail from the same shrew as in (F) (X 300), having a twist and hollows. 



Fig. 1. 


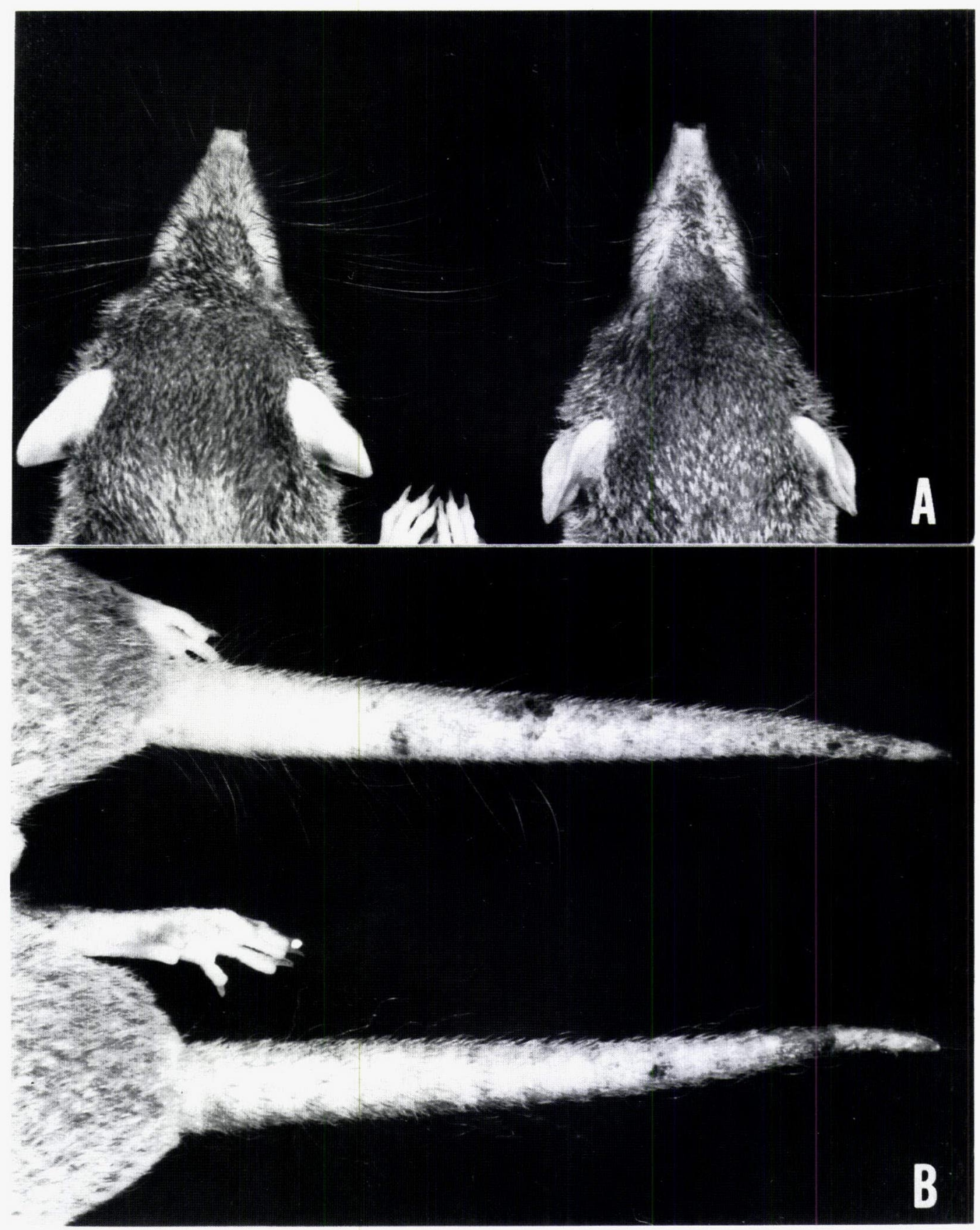

Fig. 2. 


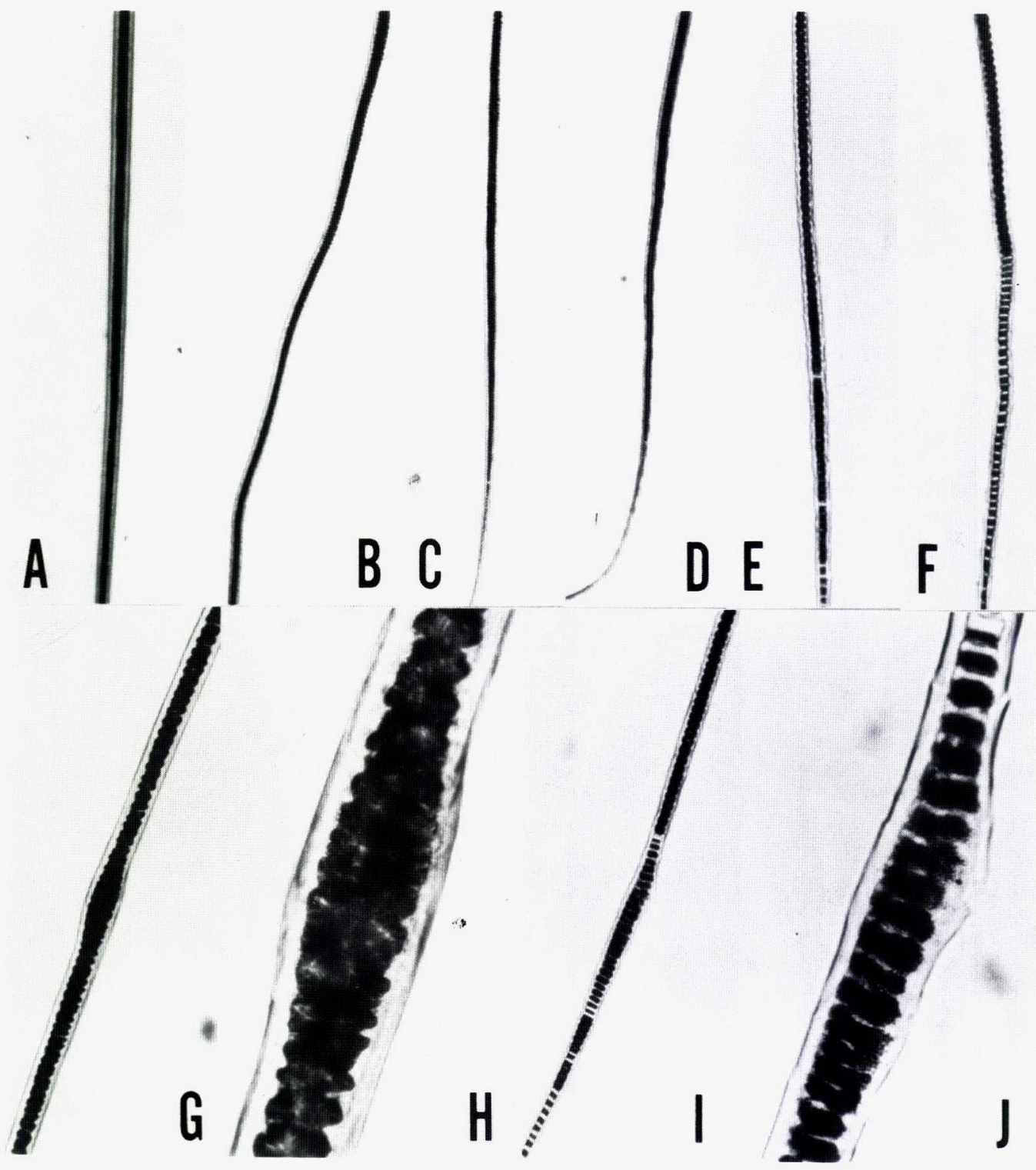

Fig. 3. 


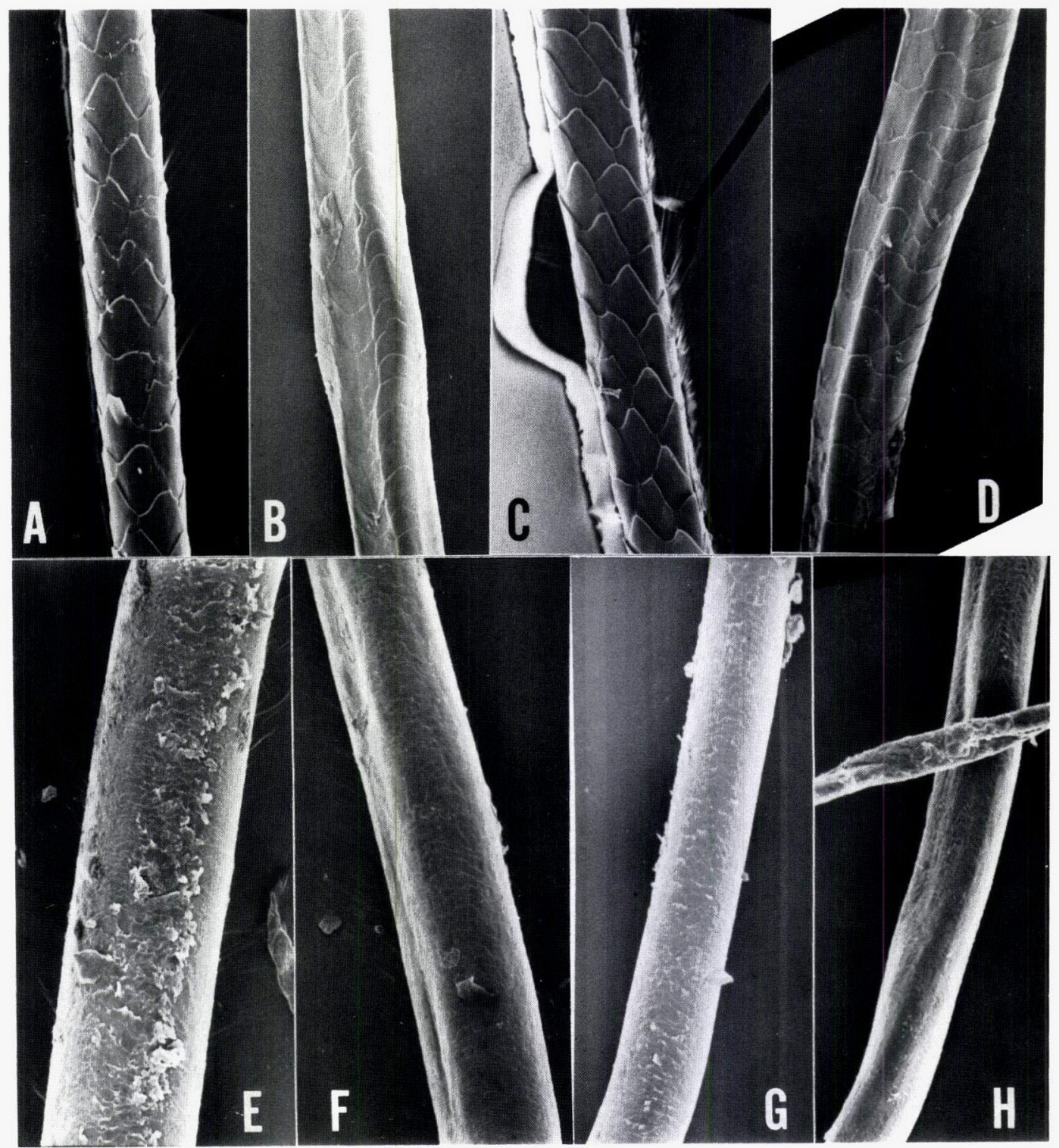

Fig. 4. 